\title{
Phase I trial of the combination of the Akt inhibitor nelfinavir and chemoradiation for locally advanced rectal cancer
}

Citation for published version (APA):

Buijsen, J., Lammering, G., Jansen, R. L., Beets, G. L., Wals, J., Sosef, M., Den Boer, M. O., Leijtens, J., Riedl, R. G., Theys, J., \& Lambin, P. (2013). Phase I trial of the combination of the Akt inhibitor nelfinavir and chemoradiation for locally advanced rectal cancer. Radiotherapy and Oncology, 107(2), 184-188. https://doi.org/10.1016/j.radonc.2013.03.023

Document status and date:

Published: 01/05/2013

DOI:

10.1016/j.radonc.2013.03.023

Document Version:

Publisher's PDF, also known as Version of record

Document license:

Taverne

Please check the document version of this publication:

- A submitted manuscript is the version of the article upon submission and before peer-review. There can be important differences between the submitted version and the official published version of record.

People interested in the research are advised to contact the author for the final version of the publication, or visit the DOI to the publisher's website.

- The final author version and the galley proof are versions of the publication after peer review.

- The final published version features the final layout of the paper including the volume, issue and page numbers.

Link to publication

\footnotetext{
General rights rights.

- You may freely distribute the URL identifying the publication in the public portal. please follow below link for the End User Agreement:

www.umlib.nl/taverne-license

Take down policy

If you believe that this document breaches copyright please contact us at:

repository@maastrichtuniversity.nl

providing details and we will investigate your claim.
}

Copyright and moral rights for the publications made accessible in the public portal are retained by the authors and/or other copyright owners and it is a condition of accessing publications that users recognise and abide by the legal requirements associated with these

- Users may download and print one copy of any publication from the public portal for the purpose of private study or research.

- You may not further distribute the material or use it for any profit-making activity or commercial gain

If the publication is distributed under the terms of Article $25 \mathrm{fa}$ of the Dutch Copyright Act, indicated by the "Taverne" license above, 
Phase I trial

\title{
Phase I trial of the combination of the Akt inhibitor nelfinavir and chemoradiation for locally advanced rectal cancer
}

\author{
Jeroen Buijsen $^{\text {a,*}}{ }^{\text {, Guido Lammering }}{ }^{\text {a }}$, Rob L.H. Jansen ${ }^{b}$, Geerard L. Beets ${ }^{c}$, Jaap Wals ${ }^{\text {d }}$, Meindert Sosef ${ }^{\mathrm{e}}$, \\ Marien O. Den Boer ${ }^{\mathrm{f}}$, Jeroen Leijtens ${ }^{\mathrm{g}}$, Robert G. Riedl ${ }^{\mathrm{h}}$, Jan Theys ${ }^{\mathrm{i}}$, Philippe Lambin ${ }^{\mathrm{a}}$ \\ ${ }^{\mathrm{a}}$ Dept. of Radiation Oncology (MAASTRO Clinic), GROW - School for Oncology and Developmental Biology; ${ }^{\mathrm{b}}$ Dept. of Internal Medicine; ${ }^{\mathrm{c}}$ Dept. of Surgery, Maastricht \\ University Medical Centre; ${ }^{\mathrm{d}}$ Dept. of Internal Medicine; ${ }^{\mathrm{e}}$ Dept. of Surgery, Atrium Medical Centre, Heerlen; ${ }^{\mathrm{f}}$ Dept. of Internal Medicine; ${ }^{\mathrm{g}}$ Dept. of Surgery, Laurentius Hospital, \\ Roermond; ' Dept. of Pathology, Maastricht University Medical Centre, The Netherlands; ${ }^{\mathrm{i}}$ Dept. of Radiation Oncology (MAASTRO Lab), GROW - School for Oncology \\ and Developmental Biology, Maastricht University Medical Centre, The Netherlands
}

\section{A R T I C L E I N F O}

\section{Article history:}

Received 27 November 2012

Received in revised form 8 March 2013

Accepted 17 March 2013

Available online 3 May 2013

\section{Keywords:}

Rectal cancer

Chemoradiation

Phase I

Nelfinavir

\begin{abstract}
A B S T R A C T
Purpose: To investigate the toxicity of nelfinavir, administered during preoperative chemoradiotherapy (CRT) in patients with locally advanced rectal cancer.

Material and methods: Twelve patients were treated with chemoradiotherapy to 50.4 Gy combined with capecitabine $825 \mathrm{mg} / \mathrm{m}^{2}$ BID. Three dose levels (DL) of nelfinavir were tested: $750 \mathrm{mg}$ BID (DL1), $1250 \mathrm{mg}$ BID (DL2) and an intermediate level of $1000 \mathrm{mg}$ BID (DL3). Surgery was performed between 8 and 10 weeks after completion of CRT. Primary endpoint was dose-limiting toxicity (DLT), defined as any grade 3 or higher non-hematological or grade 4 or higher hematological toxicity.

Results: Eleven patients could be analyzed: 5 were treated in DL1, 3 in DL2 and 3 in DL3. The first 3 patients in DL1 did not develop a DLT. In DL2 one patient developed gr 3 diarrhea, 1 patient had gr 3 transaminase elevation and 1 patient had a gr 3 cholangitis with unknown cause. An intermediate dose level was tested in DL3. In this group 2 patients developed gr 3 diarrhea and 1 patient gr 3 transaminase elevation and gr 4 post-operative wound complication. Three patients achieved a pathological complete response (pCR).

Conclusions: Nelfinavir $750 \mathrm{mg}$ BID was defined as the recommended phase II dose in combination with capecitabine and $50.4 \mathrm{~Gy}$ pre-operative radiotherapy in rectal cancer. First tumor response evaluations are promising, but a further phase II study is needed to get more information about efficacy of this treatment regimen.
\end{abstract}

(C) 2013 Elsevier Ireland Ltd. All rights reserved. Radiotherapy and Oncology 107 (2013) 184-188
Pre-operative radiotherapy plays an important role in the treatment of rectal cancer. It improves local control and may increase the chance of sphincter-saving surgery $[1,2]$ and is often combined with chemotherapy to enhance the effect of radiotherapy [3]. The most frequently used combination is 5-fluorouracil or capecitabine and radiotherapy to doses around 45-50.4 Gy, resulting in pathological complete response (pCR) rates of $10-33 \%$, depending on radiation dose and the interval between completion of treatment and surgery [4-6]. Patients who develop a complete response have a better prognosis $[7,8]$ and may be candidates for less invasive surgery or even a wait-and-see policy [9].

PI3Ks are frequently altered in human colorectal cancers [1013 ] and the PI3K signaling pathway can be constitutively activated in colorectal cancer [14]. As PI3K mutations seem to be common in colorectal cancer, inhibition of the PI3K pathway may well be able

\footnotetext{
* Corresponding author. Address: MAASTRO Clinic, P.O. Box 1345, 6201 BH Maastricht, The Netherlands.

E-mail address: jeroen.buijsen@maastro.nl (J. Buijsen).
}

to influence the response to radiation. However, up until now, no clinically usable PI3K inhibitors have been available.

HIV protease inhibitors (HPIs) are a group of drugs that have been used for more than a decade in the treatment of HIV as part of highly active anti-retroviral therapy (HAART). HPIs have been shown to possess anti-tumor activity that is independent of their anti-retroviral activity and to have a radiosensitizing effect through the inhibition of phosphorylated-Akt (pAKT) [15]. The inhibition of PI3K during radiotherapy is not expected to result in increased normal tissue toxicity because this pathway is not constitutively activated in normal cells. No specific pre-clinical data are available for colorectal cancer cells, but it has been shown in vitro that inhibition of the PI3K/Akt pathway leads to radiosensitization of different cell lines in vitro and in vivo, including colon cancer, bladder cancer and glioma cell lines [16-18]. Therefore, we hypothesized that the addition of an HPI to chemoradiation for rectal cancer would increase the effect of treatment, resulting in a higher percentage of $\mathrm{pCR}$. Due to the extensive clinical experience with HPIs in HIV treatment, they form an interesting group of Akt inhibitors to test in clinical practice. The HPI nelfinavir was the 
most potent inhibitor of the PI3K-Akt pathway in pre-clinical studies. In HAART therapy it is prescribed in a dose of $1250 \mathrm{mg}$ BID and the most commonly observed side-effects are diarrhea $(>10 \%)$ and transaminase elevations (around 2\%) and nausea.

Since there is room for improvement in the number of pCRs, we felt it was worthwhile to set up a phase I trial testing the combination of different nelfinavir dose levels with capecitabine and radiotherapy. The primary endpoint was to evaluate the toxicity of this combined modality treatment in order to find the recommended phase II dose (RP2D).

\section{Patients, materials, and methods}

The aim of this phase I study was to define the RP2D of nelfinavir in combination with capecitabine $825 \mathrm{mg} / \mathrm{m}^{2}$ and radiotherapy in patients with cT3-4N0-2M0 (staging based on MRI) rectal cancer. Two dose levels (DLs 1 and 2) of nelfinavir were planned to test with the possibility of exploring an intermediate DL3 if DL2 turned out to be too toxic: $750 \mathrm{mg}$ BID (DL1), $1250 \mathrm{mg}$ BID (DL2) and $1000 \mathrm{mg}$ BID (DL3). Nelfinavir plasma levels were monitored in weeks two, four and six, using an HPLC-UV method [19]. To correct for the different timepoints at which samples for drug level measurement were taken, the drug concentration ratio (CR) was calculated for each sample [20] by dividing the drug concentration measured in that sample by the time-adjusted value in the standardized pharmacokinetic curve. Nelfinavir doses were adjusted if CRs were lower than 0.90 or higher than 1.5. Dose limiting toxicity was defined as any grade 3 or more non-hematologic toxicity, any grade 4 or more hematologic toxicity or any grade 4 or higher post-operative toxicity within 30 days post-surgery (NCI-CTCAE v3.0). Surgical resection was performed preferably between eight to ten weeks after the end of CRT. Patients who had node-positive disease received adjuvant chemotherapy (capacitabine/oxaliplatin). According to the protocol of the referring hospital, 1 or $2 \mathrm{cy}-$ cles could be administered in the interval between the completion of CRT and resection.

Tumor regression grade (TRG) was scored by one pathologist according to the Mandard scoring system [21]. In short, scores ranged from TRG5 (no changes) to TRG1 (no viable tumor cells left).

The primary objective of this study was to evaluate the safety of nelfinavir, capecitabine and radiotherapy and to identify the RP2D of nelfinavir among patients with locally advanced rectal cancer. A standard $3+3$ dose escalation design (modified Fibonacci design) was used [22].

\section{Results}

\section{Patient characteristics}

Twelve patients (five DL1, three DL2 and four DL3) were enrolled in the study between October 2008 and September 2010. One patient in DL3 had no measurable nelfinavir levels at all timepoints. Although he affirmed that he took the medication as prescribed, we decided to exclude this patient from further analysis and include an extra patient in DL2 since we judged this patient to be unrepresentative for toxicity analysis. Therefore only $11 \mathrm{pa}-$ tients were analyzed. Patient characteristics are shown in Table 1.

\section{Toxicities}

The first three DL1 patients did not experience any DLT. In DL2, one patient developed a grade 3 transaminase elevation (without clinical signs), and one patient had a grade 3 cholangitis for which no specific cause could be found. Therefore, a relationship with the treatment regimen could not be ruled out. In both patients, symptoms disappeared and lab values normalized after nelfinavir was
Table 1

Patient characteristics.

\begin{tabular}{|c|c|c|c|}
\hline Characteristic & No. of patients $(n=11)$ & & $\%$ \\
\hline \multicolumn{4}{|l|}{ Age, years } \\
\hline Median & & 61 & \\
\hline Range & & $51-72$ & \\
\hline \multicolumn{4}{|l|}{ Sex } \\
\hline Male & 10 & & 91 \\
\hline Female & 1 & & 9 \\
\hline \multicolumn{4}{|l|}{ cT stage } \\
\hline $\mathrm{T} 2$ & 2 & & 18 \\
\hline T3 & 8 & & 73 \\
\hline $\mathrm{T} 4$ & 1 & & 9 \\
\hline \multicolumn{4}{|l|}{ cN stage } \\
\hline NO & 2 & & 18 \\
\hline N1 & 4 & & 36 \\
\hline N2 & 5 & & 46 \\
\hline \multicolumn{4}{|l|}{ Tumor position } \\
\hline Low & 9 & & 82 \\
\hline Middle & 2 & & 8 \\
\hline High & 0 & & 0 \\
\hline
\end{tabular}

stopped. Radiotherapy treatment could be completed and both events were graded as DLT. The third patient had grade 2 diarrhea and developed a grade 3 ileus caused by excessive use of loperamide. This grade 3 toxicity was considered to be at most indirectly related to the use of nelfinavir. Radiotherapy had to be interrupted and stopped after $32.4 \mathrm{~Gy}$ in this case.

Because 2/3 patients developed DLT, DL2 was deemed too toxic and DL1 was expanded with another two patients, who did not experience any toxicity $\geqslant$ grade 3 . Therefore an intermediate nelfinavir dose was explored in DL3. At this dose level 2/3 patients were hospitalized for grade 3 diarrhea. Radiotherapy could be completed in both patients. The third patient showed a grade 3 transaminase elevation, again without clinical symptoms, which normalized after stopping nelfinavir and he developed a grade 4 wound complication of the abdominal wound for which surgical revision was necessary. Although a relationship between this wound complication and the study medication seems to be unlikely, it cannot be ruled out completely. Because DLT occurred in all three patients in DL3, DL1 was declared the MTD. An overview of all toxicities $\geqslant$ grade 3 is shown in Table 2 . As can be concluded from the overall treatment times (OTT) mentioned in this table, a treatment interruption of more than five days was necessary for one patient.

\section{Nelfinavir plasma levels}

Nelfinavir plasma levels turned out to be quite variable between patients. In our patient group we observed mainly high CRs: the median CRs were 1.7 (range 1.2-7.1), 1.2 (0.6-6.0) and $1.7(1.1-4.1)$, respectively in weeks two, four and six of nelfinavir use. In four patients (three in DL2 and one in DL3), the prescribed nelfinavir dose was adapted because of CRs $>1.5$. All patients who needed a dose adjustment also developed a DLT. In total 4/6 patients with DLT also had a $C R>1.5$. No clear relationship between the height of CR and the occurrence of DLT was observed.

\section{Resections, response and follow-up}

All patients underwent a radical resection. The mean interval between radiotherapy and surgery was 67 days (range: 49112 days). Table 3 shows the responses of all patients. Three patients (27\%) showed a pathological complete response. These pCRs were all observed in DL2 and 3. Taking TRG into account and considering TRG1 and 2 to be good responders, four patients had a good response (TRG1 and 2). T-downstaging was found in five 
Table 2

Acute toxicity during chemoradiation until 4 weeks post-surgery.

\begin{tabular}{|c|c|c|c|c|c|}
\hline Patient no $^{\mathrm{a}}$ & Dose level NFV & Toxicity $\geqq$ gr 3 & Dose adjustment NFV ${ }^{b}$ & Description & Relation with study medication \\
\hline 1 & 750 mg BID & $\mathrm{n}$ & $\mathrm{n}$ & & \\
\hline 2 & 750 mg BID & $\mathrm{n}$ & $\mathrm{n}$ & & \\
\hline 3 & 750 mg BID & $\mathrm{n}$ & $\mathrm{n}$ & & \\
\hline 7 & $750 \mathrm{mg}$ BID & $\mathrm{n}$ & $\mathrm{n}$ & & \\
\hline 8 & 750 mg BID & $\mathrm{n}$ & $\mathrm{n}$ & & \\
\hline 9 & 1000 mg BID & $\mathrm{y}$ & $\mathrm{y}$ & $\begin{array}{l}\text { grade } 3 \text { transaminase elevation } \\
\text { grade } 4 \text { wound dehiscence }\end{array}$ & $\begin{array}{l}\text { Likely } \\
\text { Unlikely }\end{array}$ \\
\hline 10 & 1000 mg BID & $\mathrm{y}$ & $\mathrm{y}$ & grade 3 diarrhea & Possible \\
\hline 11 & 1000 mg BID & $\mathrm{y}$ & $\mathrm{y}$ & grade 3 diarrhea & Possible \\
\hline 4 & $1250 \mathrm{mg}$ BID & $\mathrm{y}$ & $\mathrm{n}$ & grade 3 ileus & Indirectly \\
\hline 5 & $1250 \mathrm{mg}$ BID & $\mathrm{y}$ & $\mathrm{n}$ & grade 3 transaminase elevation & Likely \\
\hline 6 & 1250 mg BID & $\mathrm{y}$ & $\mathrm{y}$ & grade 3 cholangitis & Possible \\
\hline
\end{tabular}

a In chronological order of inclusion in the trial.

b Dose adjustment due to high plasma levels.

Table 3

Treatment details and response to therapy.

\begin{tabular}{|c|c|c|c|c|c|c|c|c|c|c|}
\hline $\begin{array}{l}\text { Patient } \\
\text { no. }\end{array}$ & $\begin{array}{l}\text { Dose level } \\
\text { NFV }\end{array}$ & $\begin{array}{l}\text { NFV } \\
\text { completed }\end{array}$ & $\begin{array}{l}\text { RT dose } \\
\text { (Gy) }\end{array}$ & $\begin{array}{l}\text { OTT } \\
\text { (days) }\end{array}$ & $\begin{array}{l}\text { Adj } \\
\text { chemo }^{a}\end{array}$ & $\begin{array}{l}\text { Interval RT surgery } \\
\text { (days) }\end{array}$ & $\begin{array}{l}\text { Type of } \\
\text { surgery }\end{array}$ & $\begin{array}{l}\text { cTN } \\
\text { stage }\end{array}$ & $\begin{array}{l}\text { ypTN } \\
\text { stage }\end{array}$ & $\mathrm{TRG}^{\mathrm{b}}$ \\
\hline 1 & 750 mg BID & $\mathrm{y}$ & 50.4 & 37 & $\mathrm{n}$ & 58 & APR & cT3N2 & ypT1N0 & 2 \\
\hline 2 & $750 \mathrm{mg}$ BID & $\mathrm{y}$ & 50.4 & 37 & $\mathrm{y}, 2$ & 76 & LAR & cT3N2 & ypT3NO & 3 \\
\hline 3 & 750 mg BID & $\mathrm{y}$ & 50.4 & 37 & $\mathrm{y}, 1$ & 58 & APR & cT2N2 & ypT3N2 & 4 \\
\hline 7 & $750 \mathrm{mg}$ BID & $\mathrm{y}$ & 50.4 & 39 & $\mathrm{n}$ & 49 & APR & cT3NO & ypT3N0 & 3 \\
\hline 8 & 750 mg BID & $\mathrm{y}$ & 50.4 & 38 & $\mathrm{n}$ & 59 & APR & cT3N1 & ypT3NO & 3 \\
\hline 9 & 1000 mg BID & $\mathrm{y}$ & 50.4 & 38 & $\mathrm{n}$ & 58 & APR & cT3N1 & ypTONO & 1 \\
\hline 10 & 1000 mg BID & $\mathrm{n}$ & 50.4 & 37 & $\mathrm{y}, 2$ & 71 & LAR & cT4N2 & ypTONO & 1 \\
\hline 11 & $1000 \mathrm{mg}$ BID & $\mathrm{n}$ & 50.4 & 53 & $\mathrm{n}$ & 63 & APR & cT2N1 & ypT2NO & 4 \\
\hline 4 & $1250 \mathrm{mg}$ BID & $\mathrm{n}$ & 32.4 & 23 & $\mathrm{n}$ & 112 & LAR & cT3N2 & ypT3NO & 5 \\
\hline 5 & $1250 \mathrm{mg}$ BID & $\mathrm{n}$ & 50.4 & 37 & $\mathrm{n}$ & 63 & LAR & cT3N1 & ypTONO & 1 \\
\hline 6 & $1250 \mathrm{mg}$ BID & $\mathrm{n}$ & 50.4 & 40 & $\mathrm{n}$ & 72 & LAR & cT3NO & ypT2N0 & 3 \\
\hline
\end{tabular}

a Adjuvant chemotherapy given before surgery and if yes number of cycles.

b TRG scores according to Mandard.

(45\%) patients and $\mathrm{N}$-downstaging in eight (73\%) patients. At the time of analysis, all patients were alive without local or distant recurrence with a follow-up between five and 27 months.

\section{Discussion}

This study demonstrates that the combination of capecitabine, radiotherapy and nelfinavir is feasible, although the RP2D in this combination turned out to be the lowest dose level tested (750 mg BID). This is the third phase I study evaluating the use of a protease inhibitor in combination with chemotherapy and radiotherapy and the first study in rectal cancer patients. The other studies evaluated pancreatic cancer and non-small cell lung cancer patients $[23,24]$. In these studies, nelfinavir was added to radiotherapy combined with gemcitabine and cisplatin in the pancreas trial and radiotherapy and cisplatinum and etoposide in the lung trial. In contrast to our observations, no DLT related to the study medication was observed in both studies, which may be explained by the different chemotherapies used in both studies and the different toxicity profiles of radiation of the upper abdomen versus the pelvic region.

In this study design we chose to escalate the dose of nelfinavir because the combination of radiotherapy and capecitabine in a dose of $825 \mathrm{mg} / \mathrm{m}^{2}$ is already well established and widely used. Diarrhea is a well-known side effect of this treatment regimen. In a recent series of patients treated with radiotherapy and capecitabine, severe diarrhea (grade 3 ) was observed in $10.2 \%$ of patients [25]. Furthermore, diarrhea has been reported in up to $50 \%$ of patients treated with capecitabine monotherapy, of which $15 \%$ was classified as severe diarrhea [26]. Because diarrhea is also a frequently occurring side effect of nelfinavir [27], we decided to start with a relatively low dose ( $750 \mathrm{mg}$ BID) of this drug. In pre-clinical studies, nelfinavir has been tested at concentrations normally achieved in HIV positive patients treated with HAART and it has been shown that higher doses only slightly increased radiation response. Therefore, the dose used in HIV treatment (1250 mg BID) was used as the highest dose level.

Diarrhea was observed frequently in this study. Severe diarrhea ( $\geqslant$ grade 3 ) was only observed in DL2 and DL3. Patients who have a deficiency in dihydropyrimidine dehydrogenase (DPD), an important enzyme in the metabolism of 5-FU of which capecitabine is a prodrug, can develop severe toxicity during capecitabine use. Although patients in this study were not tested for DPD deficiency, we had no clinical suspicion of such a deficiency as these patients often develop severe toxicity of multiple organ systems, including a very pronounced mucositis, early during treatment.

It was quite remarkable that two patients showed grade 3 transaminase elevations and one patient developed a grade 3 cholangitis. All patients in this study had normal liver function tests before start of treatment. In trials testing nelfinavir for treatment of HIV, the reported incidence of transaminase elevations was around $2 \%$, thus it is not a frequently occurring side effect [28]. Although elevated liver enzymes are reported frequently (1-10\%) during capecitabine monotherapy according to the product information, this side effect is often mild and seldom a reason for dose adjustments [26].

Hepatotoxicity has also been described with the use of HPIs, though the reported rate of severe hepatotoxicity differs between different HPIs. None of the patients in this study had a pre-existing 
liver disease. In a meta-analysis including four studies looking at hepatotoxicity, nelfinavir showed the lowest rate of transaminase elevations as compared to other HPIs [28]. No additive effect of liver toxicity between capecitabine and nelfinavir was described in the literature. It is not clear whether the case of cholangitis was treatment related, but no other clear cause could be found. Therefore a relationship with the study drug could not be ruled out.

One of the downsides of nelfinavir is that plasma levels can vary importantly between patients and that there is an interaction with a broad group of drugs [29]. In the treatment of HIV patients, concentration ratios $<0.90$ are frequently observed [20]. In our patient group, we mainly observed CRs that were higher than expected: the dose adjustments were all results of too-high plasma levels. Four out of six patients who developed DLT also needed a dose adjustment of NFV because of high plasma levels. Although the most important $\mathrm{P} 450$ isoenzymes in the metabolism of nelfinavir are CYP3A and CYP2C19, CYP2C9 is also involved. Capecitabine is an inhibitor of CYP2C9. This could be a possible explanation of the relative high nelfinavir plasma levels requiring dose adjustments. In an important part of the Caucasian population polymorphisms of CYP2C19 and CYP2C9 have been described [30]. These polymorphisms can also lead to a different metabolism. Another possible explanation could be a different absorption of nelfinavir due to mucosa changes in the gastrointestinal tract caused by nelfinavir. From the experience in HIV treatment no connection between high plasma levels and toxicity has been described. Although our observations indicate a possible relationship between high NFV plasma levels and toxicity, the number of patients in this phase I trial is too small to draw conclusions.

Three of 11 patients (27\%) had a pathological complete response and four of 11 patients (36\%) had a major response taking TRG into account. Although the response rate was rather high (27\% pCR and $36 \%$ major response) compared to response rates reported in trials using a comparable chemoradiation regimen [7], no conclusions can be drawn about the additive effect of nelfinavir because of the small sample.

The radiosensitizing effects of HPIs have been attributed to several mechanisms: inhibition of Akt phosphorylation [15], proteasome inhibition, the inhibition of matrix metalloproteinases and immunomodulatory effects [31], as well as stimulation of apoptosis and autophagy [32] and improvement of vascular flow and decrease of hypoxia $[33,34]$. In combination with radiation, HPIs have effects on endothelial cells, leading to increased apoptosis of endothelial cells and blockage of endothelial cell migration and organization [35]. It is important to note that these mechanisms occur at different nelfinavir concentrations in laboratory studies.

In conclusion, this study shows that the combination of nelfinavir with capecitabine-based chemoradiation in locally advanced rectal cancer is feasible, but the toxicity rates are rather high. From this phase I trial, nelfinavir 750 mg BID turned out to be the RP2D. A further phase II study is needed to learn more about the safety and efficacy of this combination treatment.

\section{Acknowledgements}

We acknowledge financial support from the MAASTRO Cancer Foundation, EU 7th framework program (METOXIA, EURECA), Interreg (http://www.eurocat.info) and the Dutch Cancer Society (KWF UM 2008-4210, UM 2009-4454). The protocol has been developed during the 8th FECS/AACR/ASCO workshop "Methods in Clinical Cancer Research".

The authors wish to thank Prof. Dr. Burger, Radboud University Nijmegen, for his advice in the discussion about possible pharmacokinetic mechanisms.

This work has been presented during the ASTRO 53rd Annual Meeting, Miami Beach, Florida.

\section{References}

[1] Cunningham D, Atkin W, Lenz HJ, et al. Colorectal cancer. Lancet 2010;375:1030-47.

[2] Mohiuddin M, Marks J, Marks G. Management of rectal cancer: short- vs. longcourse preoperative radiation. Int J Radiat Oncol Biol Phys 2008;72:636-43.

[3] Valentini V, Aristei C, Glimelius B, et al. Multidisciplinary rectal cancer management: 2nd european rectal cancer consensus conference (EURECACC2). Radiother Oncol 2009;92:148-63.

[4] Balch GC, De Meo A, Guillem JG. Modern management of rectal cancer: a 2006 update. World J Gastroenterol 2006;12:3186-95.

[5] Kim DW, Huamani J, Fu A, Hallahan DE. Molecular strategies targeting the host component of cancer to enhance tumor response to radiation therapy. Int J Radiat Oncol Biol Phys 2006;64:38-46.

[6] Wiltshire KL, Ward IG, Swallow C, et al. Preoperative radiation with concurrent chemotherapy for resectable rectal cancer: effect of dose escalation on pathologic complete response, local recurrence-free survival, disease-free survival, and overall survival. Int J Radiat Oncol Biol Phys 2006;64:709-16.

[7] Maas M, Nelemans PJ, Valentini V, et al. Long-term outcome in patients with a pathological complete response after chemoradiation for rectal cancer: a pooled analysis of individual patient data. Lancet Oncol 2010;11:835-44.

[8] Valentini V, Lambin P, Myerson RJ. Is it time for tailored treatment of rectal cancer? From prescribing by consensus to prescribing by numbers. Radiother Oncol 2012;102:1-3.

[9] Maas M, Beets-Tan RG, Lambregts DM, et al. Wait-and-see policy for clinical complete responders after chemoradiation for rectal cancer. J Clin Oncol 2011;29:4633-40.

[10] Barault L, Veyrie N, Jooste V, et al. Mutations in the RAS-MAPK, PI(3)K (phosphatidylinositol-3-OH kinase) signaling network correlate with poor survival in a population-based series of colon cancers. Int $\mathrm{J}$ Cancer 2008;122:2255-9.

[11] He Y, Van't Veer LJ, Mikolajewska-Hanclich I, et al. PIK3CA mutations predict local recurrences in rectal cancer patients. Clin Cancer Res 2009;15:6956-62.

[12] Liao X, Morikawa T, Lochhead P, et al. Prognostic role of PIK3CA mutation in colorectal cancer: cohort study and literature review. Clin Cancer Res 2012;18:2257-68.

[13] Samuels Y, Wang Z, Bardelli A, et al. High frequency of mutations of the PIK3CA gene in human cancers. Science 2004;304:554.

[14] Vivanco I, Sawyers CL. The phosphatidylinositol 3-Kinase AKT pathway in human cancer. Nat Rev Cancer 2002;2:489-501.

[15] Gupta AK, Cerniglia GJ, Mick R, McKenna WG, Muschel RJ. HIV protease inhibitors block Akt signaling and radiosensitize tumor cells both in vitro and in vivo. Cancer Res 2005;65:8256-65.

[16] Gupta AK, Cerniglia GJ, Mick R, et al. Radiation sensitization of human cancer cells in vivo by inhibiting the activity of PI3K using LY294002. Int J Radiat Oncol Biol Phys 2003;56:846-53.

[17] Gupta AK, Bakanauskas VJ, Cerniglia GJ, et al. The Ras radiation resistance pathway. Cancer Res 2001;61:4278-82.

[18] Jiang W, Mikochik PJ, Ra JH, et al. HIV protease inhibitor nelfinavir inhibits growth of human melanoma cells by induction of cell cycle arrest. Cancer Res 2007;67:1221-7.

[19] Dailly E, Raffi F, Jolliet P. Determination of atazanavir and other antiretroviral drugs (indinavir, amprenavir, nelfinavir and its active metabolite M8, saquinavir, ritonavir, lopinavir, nevirapine and efavirenz) plasma levels by high performance liquid chromatography with UV detection. J Chromatogr B Analyt Technol Biomed Life Sci 2004;813:353-8.

[20] Burger D, Hugen P, Reiss P, et al. Therapeutic drug monitoring of nelfinavir and indinavir in treatment-naive HIV-1-infected individuals. AIDS 2003;17:1157-65.

[21] Mandard AM, Dalibard F, Mandard JC, et al. Pathologic assessment of tumor regression after preoperative chemoradiotherapy of esophageal carcinoma. Clinicopathologic correlations. Cancer 1994;73:2680-6.

[22] Pijls-Johannesma M, van Mastrigt G, Hahn SM, et al. A systematic methodology review of phase I radiation dose escalation trials. Radiother Oncol 2010;95:135-41.

[23] Brunner TB, Geiger M, Grabenbauer GG, et al. Phase I trial of the human immunodeficiency virus protease inhibitor nelfinavir and chemoradiation for locally advanced pancreatic cancer. J Clin Oncol 2008;26:2699-706.

[24] Rengan R, Mick R, Pryma D, et al. A phase I trial of the HIV protease inhibitor nelfinavir with concurrent chemoradiotherapy for unresectable stage IIIA/IIIB non-small cell lung cancer: a report of toxicities and clinical response. J Thorac Oncol 2012;7:709-15.

[25] Swellengrebel HA, Marijnen CA, Verwaal VJ, et al. Toxicity and complications of preoperative chemoradiotherapy for locally advanced rectal cancer. $\mathrm{Br} \mathrm{J}$ Surg 2011;98:418-26.

[26] Walko CM, Lindley C. Capecitabine: a review. Clin Ther 2005;27:23-44.

[27] Viracept ${ }^{\circledR}$. Prescribing Information. APILJ, CA 92037, USA Item \#634200MV; 2001.

[28] Bruno R, Sacchi P, Maiocchi L, Zocchetti C, Filice G. Hepatotoxicity and nelfinavir: a meta-analysis. Clin Gastroenterol Hepatol 2005;3:482-8.

[29] Perry CM, Frampton JE, McCormack PL, Siddiqui MA, Cvetkovic RS. Nelfinavir: a review of its use in the management of HIV infection. Drugs 2005;65:2209-44.

[30] Kurose K, Sugiyama E, Saito Y. Population differences in major functional polymorphisms of pharmacokinetics/pharmacodynamics-related genes in 
Eastern Asians and Europeans: implications in the clinical trials for novel drug development. Drug Metab Pharmacokinet 2012;27:9-54.

[31] Monini P, Sgadari C, Toschi E, Barillari G, Ensoli B. Antitumour effects of antiretroviral therapy. Nat Rev Cancer 2004;4:861-75.

[32] Gills JJ, Lopiccolo J, Tsurutani J, et al. Nelfinavir, a lead HIV protease inhibitor, is a broad-spectrum, anticancer agent that induces endoplasmic reticulum stress, autophagy, and apoptosis in vitro and in vivo. Clin Cancer Res 2007; 13:5183-94.
33] Qayum N, Muschel RJ, Im JH, et al. Tumor vascular changes mediated by inhibition of oncogenic signaling. Cancer Res 2009;69:6347-54.

[34] Fokas E, Im JH, Hill S, et al. Dual inhibition of the PI3K/mTOR pathway increases tumor radiosensitivity by normalizing tumor vasculature. Cancer Res 2012;72:239-48.

[35] Cuneo KC, Tu T, Geng L, Fu A, Hallahan DE, Willey CD. HIV protease inhibitors enhance the efficacy of irradiation. Cancer Res 2007;67:4886-93. 